Iwona Salejko-Szyszczak

\title{
KLASYFIKACJA KONFLIKTÓW W PRZEDSIĘBIORSTWIE
}

Z a r y s treś c i. Artykuł ma charakter poznawczy. Jego celem jest przedstawienie podstawowych rodzajów konfliktów w zależności od kryteriów ich podziału. Wielość zaistniałych w praktyce sytuacji konfliktowych utrudnia właściwe ich sklasyfikowanie, co niewątpliwie jest przeszkodą w ich rozpoznaniu i opóźnia proces ich rozwiązania. Znajomość poszczególnych typów konfliktów może przyczynić się do właściwego przyporządkowania zaistniałych sytuacji konfliktowych. Syntetyczna ich charakterystyka może być przyczynkiem do szybszego ich rozwiązania.

Słow a kluczowe: konflikty, przedsiębiorstwo.

\section{WSTĘP}

Konflikty są istotnym elementem kontaktów między ludźmi. Są one także najbardziej widocznymi przejawami zakłócenia relacji interpersonalnych we wszystkich przedsiębiorstwach. Pojęcie „konflikt” pochodzi od łacińskiego słowa conflictus - zderzenie. Potocznie oznacza ono zetknięcie się sprzecznych dążeń, niezgodność interesów, poglądów, antagonizm, kolizję postaw, spór, zatarg (Stownik wyrazów obcych, 1980, s. 378).

W każdym konflikcie można wyróżnić:

- partnerów (strony, podmioty) konfliktu - najczęściej stronami konfliktów w przedsiębiorstwie są grupy ludzi;

- przedmiot konfliktu - mogą to być rzeczy materialne, poglądy stron lub relacje między stronami, im jest on ważniejszy dla partnerów sporu, tym mniejsza szansa na to, że zechcą oni zrezygnować z osiągnięcia zamierzonego celu; 
- źródła (przyczyny) konfliktu - mogą one wynikać zarówno z przesłanek psychologicznych jak i społecznych;

- skutki konfliktu - uzyskują one różną ocenę w zależności od wartości, jakie preferują uczestnicy (Bańka, 1998, s. 142; Karney, 1998, s. 104-105).

Konflikt może mieć różny stopień:

- jawności - często jest on ukrywany, bowiem przedsiębiorstwa obawiają się, że jego ujawnienie doprowadzi do niekorzystnych zachowań klientów; czas trwania konfliktu jest pozytywnie skorelowany z jego jawnością;

- ostrości - duży stopień ostrości przyczynia się do szybszego ujawnienia konfliktu;

- aktywności - z jednej strony znajduje się tu kooperacja negatywna stron, czyli sytuacja, w której przynajmniej jedna ze stron przeszkadza drugiej w dążeniu do celu, z drugiej zaś jest skrajny przypadek przeszkadzania, czyli uniemożliwienia osiągnięcia celu;

- trwałości - wynika głównie z cech osobowości poszczególnych ludzi (Bednarski, 1998, s. 145; Zieleniewski, 1969, s. 319-325).

Każdy konflikt ma swoją dynamikę i rozwija się, przechodząc przez szereg etapów. Cykl konfliktowy składa się z następujących stadiów rozwoju:

- stadium utajnienia - nie ma ono jeszcze cech otwartego konfliktu, istnieje jednak potencjalna przyczyna, która mogła go wywołać; konflikt przybiera tu formę niedomówień, plotek, obaw i niepokojów;

- stadium dostrzeżenia - pojawiają się tu kwestie sporne o podłożu problemowym w postrzeganiu rzeczywistości;

- stadium odczuwania - można tu zauważyć emocje frustracyjne, odczuwane przynajmniej przez jedną ze stron, która czuje, że druga strona blokuje, zakłóca lub uniemożliwia realizację interesów;

- stadium demonstracji - następuje wybuch konfliktu, przybiera on formę otwartą, strony w większym stopniu uświadamiają sobie przedmiot sporu i zachowują się w sposób agresywny (kłócą się, walczą, zrywają współpracę itp.); w fazie tej jest już za późno na wycofanie się, trzeba wówczas tym konfliktem pokierować; etap ten jest często utożsamiany z całym procesem konfliktowym albo chociaż uważany za jego najważniejszy moment;

- stadium „po bitwie” - konflikt zostaje rozwiązany lub stłumiony, dąży się do tego, aby obie strony były usatysfakcjonowane i nie weszły ponownie w stan frustracji; dla menedżera zakończenie konfliktu stanowi ulgę, ale jednocześnie potrzebę określenia jego przyczyn i skutków, a także podjęcia środków zmierzających do uniknięcia go w przyszłości 
(Bieniok i in., 1997, s. 238-239; Zbiegień-Maciąg, Pawnik, 1995, s. 59-60; Królikowska, 1996, s. 19-21).

Celem artykułu jest przedstawienie podstawowych rodzajów konfliktów, biorąc pod uwagę różne kryteria ich podziału. Wielość zaistniałych w praktyce sytuacji konfliktowych utrudnia właściwe ich sklasyfikowanie, co niewątpliwie jest przeszkodą w ich rozpoznaniu i opóźnia proces ich rozwiązania. Znajomość poszczególnych typów konfliktów może przyczynić się do właściwego przyporządkowania zaistniałych sytuacji konfliktowych. Syntetyczna ich charakterystyka może być przyczynkiem do szybszego ich rozwiązania.

\section{RODZAJE KONFLIKTÓW}

Konflikty mogą być rozpatrywane na różnych płaszczyznach. W zależności od przyjętych kryteriów można określić wiele ich typologii.

Ze względu na przedmiot konfliktu można wyróżnić konflikty: ekonomiczne, socjalne, polityczne, warstwowe, klasowe, ideologiczne, kulturowe, wartości i celów (Sztumski, 1987, s. 110). Konflikty ekonomiczne wynikają z zasad podziału pracy i płacy oraz związanych z tym różnic między ludźmi w sferze majątkowej, społecznej, w wyglądzie zewnętrznym i w warunkach życia codziennego. Konflikty socjalne powstają na tle spraw bytowych. Konflikty polityczne są związane ze złożonością społeczeństw w ramach poszczególnych państw i narodów (konflikty na tle rasowym, narodowościowym itp.) (Zbiegień-Maciąg, Pawnik, 1995, s. 58). Konflikty warstwowe pojawiają się w związku z rozwarstwieniem społeczeństwa, czyli w związku z procesem formowania się różnych warstw, np. ze względu na stopień prestiżu, kwalifikacje, zamożność. Przedmiotem takich konfliktów może być wszystko, co sprawia, że dana warstwa istnieje. Źródłem konfliktów klasowych są różnice, jakie występują między klasami społecznymi. Mogą to być konflikty na płaszczyźnie ekonomicznej, politycznej i ideologicznej. Ujawniają się w nich interesy klasowe. Podstawą konfliktów ideologicznych są różne wartości ideowe, jakie tkwią u podstaw ideologii danej grupy. Mogą one występować: między klasami, w obrębie danej klasy oraz między przeróżnymi grupami, np. narodowościowymi, wyznaniowymi, politycznymi itd. Globalizacja powoduje, że konflikty mogą wynikać z różnic kulturowych między społecznościami pracującymi w danej organizacji. Społeczeństwa o podobnych kulturach zacieśniają więzi między sobą. $Z$ jednej strony powstają sojusze na płaszczyźnie tolerancji, a z drugiej strony ujawniają się bariery (szczególnie w przypadku akcentowania zewnętrznych atrybutów kulturowych, religijnych czy etnicznych). Ludzie reprezentujący różne kultury, systemy i organizacje pracy różnią się ideałami i stylami życia, występują różnice etniczne i językowe (np. konflikty między 
Europejczykami a Azjatami). Kultura organizacyjna powinna być skierowana w stronę zapewnienia koegzystencji różnych kultur i wartości poprzez wzajemne poznanie się. Ważna jest wiedza o obyczajowości danego narodu, aby znaleźć wspólny język i nie popaść w konflikt, np. z przełożonym obcokrajowcem (Balcerowicz, 2011, s. 20-22). Konflikty wartości i celów występują w związku z przynależnością człowieka do wielu grup społecznych o charakterze rodzinnym, religijnym, politycznym itp., realizujących programowo trudne do pogodzenia, rozbieżne wartości i cele (Sztumski, 1987, s. 110-112).

Stosując podmiotowe kryterium klasyfikacji, można najogólniej wyodrębnić konflikty jednostkowe i konflikty zbiorowe (McKenn, Beech, 1997, s. 236; Buchanan, Huczyński, 1997, s. 633). Konflikty jednostkowe (intrapersonalne, indywidualne, wewnętrzne) dotyczą pojedynczego człowieka i wynikają z konieczności dokonywania wyboru w sferze celów, postaw i zachowań, co często prowadzi do powstawania stanów wewnętrznego napięcia i frustracji. Taki niepokój uwidacznia się najczęściej w momencie pojawienia się dwóch pozytywnych wariantów, dwóch negatywnych wariantów lub wówczas, gdy człowiek musi decydować o czymś, co przyniesie mu zarówno pozytywne, jak i negatywne skutki. Konflikty te rozgrywają się w psychice jednej osoby (pracownika, kierownika) (Pocztowski, 1998, s. 282-283; Zimniewicz, 1991, s. 90; Kuc, 1999, s. 217-218). Do konfliktów zbiorowych możemy zaliczyć konflikty: interpersonalne, intragrupowe, intergrupowe i interorganizacyjne. Konflikty interpersonalne występują między dwiema osobami lub większą ich liczbą, których poglądy, cele, postawy są sprzeczne. Każda ze stron w tym konflikcie działa we własnym imieniu, prezentuje własne interesy i swoje stanowisko (Bartkowiak, 1997, s. 70-71). W zakładzie pracy tego rodzaju konflikty rozgrywane są zwykle w trzech płaszczyznach:

- między przełożonym a podwładnym (np. w wyniku nieporozumień odnośnie do wydawanych poleceń, braku umiejętności ich wykonania, nieprecyzyjnych kryteriów oceny, niesprawiedliwej oceny pracownika),

- między równorzędnymi kierownikami (np. w wyniku dążenia do pozyskania coraz większej władzy, chęci zdobycia dominującej pozycji, podniesienia swojego prestiżu),

- między podwładnymi (mają różnorodne źródła, często banalne, zwykle szybko wygasają) (Kuc, 1999, s. 219-220).

Konflikty intragrupowe (wewnątrzgrupowe) zachodzą między jednostką a grupą. Wynikają one $\mathrm{z}$ rozbieżności między interesem jednostki a interesem grupy. Za źródła tego rodzaju konfliktów należy uznać różnice w postrzeganiu celów, odmienne kryteria wartości, różnice w poglądach dotyczące metod i środków realizacji zadań (Bańka, 1998, s. 144; Kuc, 1999, s. 220-221). Konflikty intergrupowe (międzygrupowe) występują między różnego rodzaju grupami 
działającymi w organizacji, najczęściej w sprawie zakresu uprawnień, decyzji i zasobów. Mogą one zaistnieć między: różnymi działami, kierownictwem i związkami zawodowymi, różnymi grupami pracowników, produkcją a kontrolą techniczną (Webber, 1990, s. 437; Pocztowski, 1998, s. 283). Przykładem konfliktów interorganizacyjnych (międzyorganizacyjnych) są konflikty między przedsiębiorstwami na tle dążenia do swoich celów. Są one uważane za zjawisko normalne, a nawet pożądane. Wyzwalają one dodatkowe siły, prowadzą do wprowadzania nowych wyrobów, technologii i usług, do niższych cen i efektywniejszego wykorzystania zasobów. Istnieje tu jednak pewien próg, po przekroczeniu którego konflikt przynosi zniszczenie (Zimniewicz, 1991, s. 90; Stoner, Wankel, 1996, s. 332; Bańka, 1998, s. 144).

Jeżeli za kryterium klasyfikacji konfliktów przyjmie się ich przyczyny, to można wyróżnić konflikty obiektywne i subiektywne. Konflikty spowodowane przyczynami obiektywnymi mogą wynikać z wadliwej organizacji współpracy, czy też współżycia ludzi w danej społeczności (strukturalny charakter przyczyn) lub z zakłóceń w działaniu struktur społecznych, będących następstwem niedomagań systemu komunikacyjnego, informacyjnego w danej organizacji (funkcjonalny charakter przyczyn). Przyczyn konfliktów subiektywnych należy upatrywać w opiniach, postawach i zachowaniach ludzkich. Przyczyny te mogą mieć charakter racjonalny (konflikty wynikające $\mathrm{z}$ realnych lub wysoce prawdopodobnych przesłanek) lub irracjonalny (konflikty wynikające z urojonych, fikcyjnych motywów, będących następstwem np. niezdolności do poprawnej oceny sytuacji) (Jędrzycki, 1985, s. 11; Sztumski, 1987, s. 116-117).

Biorąc pod uwagę podłoże konfliktów, można wyodrębnić konflikty rzeczowe i emocjonalne (personalne). Konflikty rzeczowe mają charakter pozapersonalny i ich podłożem jest różnica zdań co do załatwienia pewnych spraw czy rozwiązania problemów. Konflikty emocjonalne są skierowane na człowieka i wynikają z określonej postawy emocjonalnej w interakcji człowiek-człowiek. Mogą wiązać się z uprzedzeniami do kierownika z uwagi na styl zarządzania lub brak obiektywizmu. Mają one bardzo często charakter całkowicie irracjonalny, a ich efekt jest z reguły negatywny (Kieżun, 1997, s. 370).

Ze względu na umiejscowienie źródła konfliktów można wyodrębnić konflikty autonomiczne i wtórne. Konflikty autonomiczne znajdują swe źródło w zakładzie pracy, natomiast przyczyn konfliktów wtórnych należy szukać w jego otoczeniu. Konflikty, które powstają poza zakładem pracy, są wprowadzane bezpośrednio do zakładu lub wzmacniają konflikty autonomiczne (Rummel-Syska, 1990, s. 32).

Biorąc pod uwagę zasięg konfliktów, można wyróżnić konflikty: w mikroskali społecznej, w makroskali społecznej i w megaskali społecznej. O konfliktach w mikroskali społecznej można mówić w przypadku nieporozumień 
pojawiających się w małych grupach społecznych lub niewielkich społecznościach, w których ludzie są sobie znani, np. w przedsiębiorstwach, szkołach. Konflikty między różnymi, mniejszymi lub większymi grupami społecznymi istniejącymi w danej społeczności to konflikty występujące w makroskali społecznej. Na megaskalę społeczną rozciągają się konflikty, które obejmują swoim zasięgiem wiele społeczeństw, np.: konflikty międzynarodowe (Sztumski, 1987, s. 109-110).

Przyjmując za kryterium klasyfikacji konfliktów stopień ich nasilenia, można wymienić: spory (sprzeczki), starcia i kryzys. Spory charakteryzują się średnim stopniem nasilenia. Zdarzają się one bardzo często i trudno ich uniknąć. Nie są one jednak zagrożeniem dla więzi międzyludzkich i nie stanowią przyczyny zakłóceń w pracy. Narastające i coraz częściej powtarzające się sprzeczki przeradzają się w starcia. Dochodzi do nich, gdy kłótnie dotyczą coraz częściej różnych spraw, a chęć współpracy z drugą stroną całkowicie zanika. Pojawiają się długie okresy agresji i złości wobec drugiej strony. Najwięcej relacji konfliktowych pojawia się podczas kryzysu. W trakcie jego trwania jedna ze stron postanawia przerwać działania lub rozmowy, a nawet decyduje się na użycie przemocy fizycznej (Kuc, 1999, s. 222).

Ze względu na stopień złożoności konfliktów można wyróżnić konflikty elementarne (proste) i molekularne (złożone). Do konfliktów elementarnych należą: konflikty interesów, poznawcze i normatywne. Konflikty interesów powstają na skutek zderzenia się interesów stron. Zdarzają się, gdy określone aspiracje są postrzegane jako sprzeczne $\mathrm{z}$ aspiracjami innych. Konflikty poznawcze wynikają z różnego postrzegania i oceniania rzeczywistości. Są to konflikty w strukturach poznawczych jednostki, a więc konflikty wewnętrzne człowieka. Konflikty normatywne powstają na tle niezgodności zachowania jednej strony z oczekiwaniami i normami przyjętymi przez drugą stronę. Tego rodzaju konflikty wywołują różne reakcje emocjonalne (obwinianie innych, gniew, zemstę) i mają duży wpływ na wzmacnianie innych konfliktów. Konflikty molekularne mogą być złożone ze wszystkich typów konfliktów prostych i powstają pod wpływem eskalacji jednego konfliktu przez inne (np. konflikty interesów są wzmacniane przez konflikty normatywne) (Rummel-Syska, 1990, s. 32-35).

Jeżeli za kryterium klasyfikacji uzna się sposób przejawiania się konfliktów, to można wyróżnić: konflikty jawne i ukryte; konflikty zorganizowane (inspirowane i kierowane) i niezorganizowane (spontaniczne); konflikty łagodne i ostre. Konflikty jawne mają wyraźnie określony przedmiot i przyczyny. Ludzie otwarcie manifestują cel konfliktu, uzewnętrzniają swoje niezadowolenie, nie skrywają swych pretensji, żalów czy wrogości. W przypadku konfliktów ukrytych nie dopuszcza się do ujawnienia przyczyn. Są one widoczne w sposób pośredni. 
Ich wymiernymi wskaźnikami mogą być: spadek wydajności i efektywności pracy, pogorszenie się pozycji przedsiębiorstwa na rynku, wzrost fluktuacji czy absencji. Konflikty te są trudne do rozwiązania, bowiem obiektywnie ich nie ma. Dlatego też w interesie przedsiębiorstwa jest ujawnienie sytuacji konfliktowej, rozpoznanie jego przyczyn i rzeczowe rozładowanie napięć (Jędrzycki, 1985, s. 11; Bańka, 1998, s. 143; Haber, 1993, s. 217; Gordon, 1999, s. 278; Stownik ekonomiczny przedsiębiorcy, 1996, s. 128). Konflikty zorganizowane są świadomie wywoływane i sterowane. Są one przeprowadzane według z góry przyjętych zasad. Konflikty niezorganizowane pojawiają się spontanicznie, nie są one zaplanowane ani wcześniej omówione, nie są następstwem wstępnego porozumienia. Konflikty łagodne przejawiają się w sposób spokojny, natomiast ostre - zażarty i najczęściej trwały. Biorąc pod uwagę kryterium przejawiania się konfliktów, należy pamiętać, że podział na poszczególne ich pary nie zawsze musi być rozłączny. Konflikty mogą się charakteryzować równocześnie kilkoma właściwościami, nie wykluczając się wzajemnie (np. zarówno konflikty jawne, jak i ukryte mogą być zorganizowane lub niezorganizowane) (Zbiegień-Maciąg, Pawnik, 1995, s. 58; Jędrzycki, 1985, s. 13; Sztumski, 1987, s. 112-113).

Patrząc na charakter sprzeczności, można wyodrębnić konflikty powstałe pod wpływem działania sprzeczności: wewnętrznych i zewnętrznych, antagonistycznych i nieantagonistycznych, głównych i pobocznych. Przykładem konfliktów powstałych na skutek działania sprzeczności wewnętrznych są konflikty spowodowane dążeniem poszczególnych ludzi do załatwienia własnych egoistycznych interesów, a sprzeczności zewnętrznych - konflikty wynikające z różnic interesów poszczególnych grup w danym społeczeństwie. Za konflikty o antagonistycznym charakterze sprzeczności można uznać konflikty klasowe, natomiast o nieantagonistycznym charakterze sprzeczności - konflikty między grupami, które mimo różnic interesów łączą też wspólne wartości. Konflikty, które na danym etapie rozwoju społeczeństwa (zakładu pracy) mają zasadnicze znaczenie dla jego dalszych przeobrażeń, należy określić mianem konfliktów o głównym charakterze sprzeczności. Konflikty, których występowanie nie ma dużego wpływu na rozwój społeczeństwa (zakładu pracy), ale mogą modyfikować jego przebieg, to konflikty o pobocznym charakterze sprzeczności (Jędrzycki, 1985, s. 13; Sztumski, 1987, s. 113).

Z punktu widzenia związku między obiektywnym stanem spraw a subiektywnym postrzeganiem ich przez strony można wyróżnić konflikty: realne, przypadkowe, przemieszczone, źle przypisane, potencjalne i fałszywe. Konflikty realne to takie stany rzeczy, w których trudne do zmiany zaistniałe sprzeczności są właściwie postrzegane przez strony konfliktu. Nie są one łatwe do rozwiązania. Nieoczekiwana przez pracowników zmiana warunków pracy często prowadzi 
do pojawienia się konfliktów przypadkowych. Elastyczna postawa stron wobec zmian umożliwia szybkie rozwiązanie tego typu konfliktów. Z konfliktami przemieszczonymi mamy do czynienia wówczas, gdy występują obiektywne nieporozumienia i są one zauważane, jednak strony nie próbują ich załagodzić, lecz z różnych przyczyn sprzeczają się o inne rzeczy. Prawdziwa sprawa sporna jest zastępowana przez inną, a jej rozwiązanie nie zmienia napięcia między naprawdę spornymi kwestiami. W przypadku konfliktów źle przypisanych strony dostrzegają obiektywne przesłanki konfliktu, ale nieświadomie popadają w konflikt z niewłaściwymi osobami (np. ktoś obwinia podwładnego za to, co zlecił mu zrobić przełożony). Jeśli obiektywnie zaistniałe nieporozumienia wskazują na wystąpienie konfliktu, a nie są one zauważone, to można powiedzieć, że zdarzył się konflikt potencjalny. Konflikty fałszywe zdarzają się wówczas, gdy powstają one mimo braku obiektywnych podstaw ich pojawienia się (Balawajder, 1998, s. 99-100).

Biorąc czas trwania konfliktów jako kryterium, można je podzielić na: krótkotrwałe i długotrwałe. Konflikty krótkotrwałe są uwarunkowane wystąpieniem szybko dezaktualizujących się przyczyn, co z reguły prowadzi do szybkiego zakończenia konfliktu, jaki spowodowały. Do długotrwałych można zaliczyć konflikty klasowe, a także najczęściej polityczne i ekonomiczne (Sztumski, 1987, s. 113).

Przyjmując za kryterium skutki konfliktów, można je ująć w dwie kategorie: konflikty konstruktywne (funkcjonalne) i destrukcyjne (dysfunkcjonalne). Konflikty konstruktywne wspierają cele grupy, zwiększają jej efektywność, zapobiegają stagnacji, pobudzają do rozwoju, prowadzą do pozytywnych zmian w kontaktach, rozładowują napięcia, integrują załogę. Konflikty destrukcyjne są najczęściej wynikiem nieprawidłowego postępowania ludzi w sytuacjach konfliktowych. Przeszkadzają one w efektywnej działalności grupy. Ich skutkiem mogą być: zniszczenie współpracy, dezintegracja grup, wzajemna podejrzliwość, obniżenie wydajności i jakości pracy (Grzesiuk i in., 2001, s. 158; Kuc, 1999, s. 222; Robbins, 1998, s. 293-294; Robey, 1991, s. 155).

Z punktu widzenia skuteczności konfliktów można je podzielić na: skuteczne, nieskuteczne i przeciwskuteczne. Konflikty skuteczne prowadzą do osiągnięcia zamierzonego celu; nieskuteczne - nie pozwalają na osiągnięcie pożądanego celu; przeciwskuteczne - przeciwdziałają osiągnięciu wyznaczonego celu (Sztumski, 1987, s. 117).

Tak różnorodna klasyfikacja konfliktów stanowi niebagatelne utrudnienie w ich rozpoznaniu (zob. tab. 1).

Właściwa identyfikacja konfliktów jest bardzo ważnym etapem na drodze do ich rozwiązania. 
Tabela 1. Klasyfikacja konfliktów

\begin{tabular}{|c|c|}
\hline Kryterium klasyfikacji konfliktów & Rodzaje konfliktów \\
\hline Przedmiot konfliktów & $\begin{array}{l}\text { - ekonomiczne } \\
\text { - socjalne } \\
\text { - polityczne } \\
\text { - warstwowe } \\
\text { - klasowe } \\
\text { - ideologiczne } \\
\text { - kulturowe } \\
\text { - konflikty wartości i celów }\end{array}$ \\
\hline $\begin{array}{l}\text { Podmioty konfliktów (charakter } \\
\text { zaangażowanych podmiotów } \\
\text { konfliktów) }\end{array}$ & $\begin{array}{l}\text { - jednostkowe (interpersonalne, indywidualne wewnętrzne jednostki) } \\
\text { - zbiorowe } \\
\text { interpersonalne } \\
\text { intragrupowe (wewnątrzgrupowe) } \\
\text { intergrupowe (międzygrupowe) } \\
\text { interorganizacyjne (międzyorganizacyjne) }\end{array}$ \\
\hline Przyczyny konfliktów & $\begin{array}{l}\text { - obiektywne } \\
\text { - subiektywne } \\
\text { racjonalne } \\
\text { irracjonalne }\end{array}$ \\
\hline Podłoże konfliktów & $\begin{array}{l}\text { - rzeczowe } \\
\text { - emocjonalne (personalne) }\end{array}$ \\
\hline Umiejscowienie źródła konfliktów & $\begin{array}{l}\text { - autonomiczne } \\
\text { - wtórne }\end{array}$ \\
\hline Zasięg konfliktów & $\begin{array}{l}\text { - konflikty w mikroskali społecznej } \\
\text { - konflikty w makroskali społecznej } \\
\text { - konflikty w megaskali społecznej }\end{array}$ \\
\hline $\begin{array}{l}\text { Stopień nasilenia konfliktów między } \\
\text { grupami }\end{array}$ & $\begin{array}{l}\text { - spory (sprzeczki) } \\
\text { - starcia } \\
\text { - kryzys }\end{array}$ \\
\hline Stopień złożoności konfliktów & $\begin{array}{l}\text { - elementarne (proste) } \\
\text { normatywne } \\
\text { interesów } \\
\text { poznawcze } \\
\text { - molekularne (złożone) }\end{array}$ \\
\hline Sposób przejawiania się konfliktów & $\begin{array}{l}\text { - jawne i ukryte } \\
\text { - zorganizowane (inspirowane i kierowane) i niezorganizowane } \\
\text { - łagodne i ostre }\end{array}$ \\
\hline Charakter sprzeczności & $\begin{array}{l}\text { - konflikty o wewnętrznym charakterze sprzeczności i konflikty } \\
\text { o zewnętrznym charakterze sprzeczności } \\
\text { - konflikty o antagonistycznym charakterze sprzeczności i konflikty } \\
\text { o nieantagonistycznym charakterze sprzeczności } \\
\text { - konflikty o głównym i pobocznym charakterze sprzeczności }\end{array}$ \\
\hline $\begin{array}{l}\text { Związek między obiektywnym stanem } \\
\text { spraw a subiektywnym postrzeganiem } \\
\text { ich przez strony }\end{array}$ & $\begin{array}{l}\text { - realne } \\
\text { - przypadkowe } \\
\text { - przemieszczone } \\
\text { - źle przypisane } \\
\text { - potencjalne } \\
\text { - fałszywe }\end{array}$ \\
\hline Czas trwania konfliktów & $\begin{array}{l}\text { - długotrwałe } \\
\text { - krótkotrwałe }\end{array}$ \\
\hline Skutki konfliktów & $\begin{array}{l}\text { - konstruktywne (funkcjonalne) } \\
\text { - destrukcyjne (dysfunkcjonalne) }\end{array}$ \\
\hline Skuteczność konfliktów & $\begin{array}{l}\text { - } \text { skuteczne } \\
\text { - nieskuteczne } \\
\text { - przeciwskuteczne }\end{array}$ \\
\hline
\end{tabular}

Źródło: opracowanie własne. 


\section{PODSUMOWANIE}

Obywatele państwa, pracownicy przedsiębiorstwa, czy też członkowie mniejszych społeczności są uwikłani w różnego rodzaju stosunki, muszą współdziałać, ale jednocześnie chcą realizować własne oczekiwania. Czasem jednoczesna realizacja własnych interesów i respektowanie potrzeb innych są niemożliwe. Zaspokojenie potrzeb wszystkich członków organizacji jest niewykonalne. Konieczne jest szukanie takich rozwiązań konfliktów, które maksymalizowałyby satysfakcję wszystkich zaangażowanych stron. Może się do tego przyczynić właściwa identyfikacja sytuacji konfliktowych.

Studia literaturowe pozwoliły na wyodrębnienie wielu rodzajów konfliktów przy użyciu różnych kryteriów ich klasyfikacji. Złożoność sytuacji konfliktowych utrudnia wprawdzie ich klasyfikację, lecz wczesne ich zauważenie pozwala na właściwe ich zidentyfikowanie. Umożliwia to podjęcie kroków zmierzających do szybkiego rozwiązania konfliktu lub właściwego nim pokierowania. Znajomość kryteriów klasyfikacji konfliktów nie ustrzeże przedsiębiorstwa przed konfliktem, ale pozwoli wykorzystać jego pozytywne aspekty. Ciągła obserwacja i klasyfikacja konfliktów może przyczynić się do właściwego odczytania sygnału o złym funkcjonowaniu pewnych obszarów, takich np. jak: struktura organizacji czy komunikacja wewnątrz organizacji. Odpowiednie przyporządkowanie sytuacji konfliktowych pozwala uświadomić sobie jego stronom, że nie muszą one być czymś złym, lecz mogą przysłużyć się do znalezienia konstruktywnego ich rozwiązania. Konflikt między organizacjami (nazywany konkurencją) jest pożądaną cechą gospodarki rynkowej. Konkurencja między przedsiębiorstwami pobudza je do rozwoju, wprowadzania innowacji i efektywnego wykorzystania zasobów.

Właściwe przyporządkowanie konfliktów czasem jednak nie wystarczy, aby doprowadzić do optymalnego ich rozwiązania. Biorąc pod uwagę natężenie konfliktu, należy pamiętać, że napięcia nie mogą być zbyt silne, aby nie zakłócały one funkcjonowania organizacji. Ponadto przedłużające się (długotrwałe) konflikty przynoszą niekorzystne konsekwencje zarówno dla zaangażowanych stron, jak i całej organizacji. Dlatego warto szybko i sprawnie doprowadzić do rozwiązania sytuacji konfliktowych, aby zapobiec ich rozprzestrzenianiu się i przeciąganiu w czasie.

Radzenie sobie z konfliktem nie polega tylko na właściwej identyfikacji sytuacji konfliktowej, ale równie ważne jest znalezienie właściwej metody jej rozwiązania. Istotne jest także znalezienie określonych sposobów działania umożliwiających współpracę z drugą stroną dla obopólnej satysfakcji. Porozumienie się stron wymaga wspólnych ustaleń dotyczących wszystkich kwestii związanych z konfliktem. 


\section{LITERATURA}

Balawajder K. (1998), Komunikacja. Konflikty. Negocjacje w organizacji, Wydawnictwo Uniwersytetu Śląskiego, Katowice.

Balcerowicz P. (2011), Czy istnieja konflikty etniczne i religijne?, [w:] Kostecki W. (red.), Zaawansowane zapobieganie konfliktom, Katedra Stosunków Międzynarodowych, Szkoła Wyższa Psychologii Społecznej, Warszawa.

Bańka W. (1998), Zarządzanie personelem w przedsiębiorstwie, Wydawnictwo Adam Marszałek, Toruń.

Bartkowiak G. (1997), Psychologia zarzadzania, Wydawnictwo Akademii Ekonomicznej, Poznań.

Bednarski A. (1998), Zarys teorii organizacji i zarzadzania, Wydawnictwo TNOiK „Dom Organizatora", Toruń.

Bieniok H. i in. (1997), Metody sprawnego zarzadzania, Agencja Wydawnicza „Placet”, Warszawa 1997.

Buchanan D., Huczyński A. (1997), Organizational behaviour, Wydawnictwo Prentice Hall, Glasgow.

Gordon J. R. (1999), Organizational behaviour. A diagnostic approach, Wydawnictwo Prentice Hall, New Jersey.

Grzesiuk L. i in. (2001), Umiejętności menedżera. Psychologia stosowana dla menedżerów, Wydawnictwo Wyższej Szkoły Handlu i Prawa im. Ryszarda Łazarskiego, Warszawa.

Haber L. H. (1993), Management. Zarys zarządzania mała firma, Wydawnictwo Profesjonalnej Szkoły Biznesu, Kraków.

Jędrzycki W. (1985), Konflikt społeczny w zakładzie pracy, Wydawnictwo ANS, Warszawa.

Karney E. J. (1998), Psychologia w zarzadzaniu. Wybrane zagadnienia, Wydawnictwo Międzynarodowej Szkoły Menedżerów Sp. z o.o., Warszawa.

Kieżun W. (1997), Sprawne zarządzanie organizacją, Wydawnictwo Szkoły Głównej Handlowej, Warszawa.

Królikowska J. (1996), Struktura procesu konfliktowego, [w:] Piątek K. (red.), Konflikty społeczne $w$ procesie transformacji systemowej, Wydawnictwo Uniwersytetu Mikołaja Kopernika, Toruń.

Kuc B. R. (1999), Zarządzanie doskonałe, Wydawnictwo „Oskar-Master of Biznes”, Warszawa.

McKenn E., Beech N. (1997), Zarządzanie zasobami ludzkimi, Wydawnictwo Gebethner \& Ska, Warszawa.

Pocztowski A. (1998), Zarządzanie zasobami ludzkimi, Oficyna Wydawnicza „Antykwa”, Kraków.

Robbins S. P. (1998), Zachowanie w organizacji, Polskie Wydawnictwo Ekonomiczne, Warszawa.

Robey D. (1991), Designing organizations, Wydawnictwo Richard D. Irwin, Boston.

Rummel-Syska Z. (1990), Konflikty organizacyjne. Ujęcie mikrospołeczne, Wydawnictwo Naukowe PWN, Warszawa. 
Stownik ekonomiczny przedsiębiorcy (1996), Wydawnictwo „Znicz”, Szczecin. Stownik wyrazów obcych (1980), Wydawnictwo Naukowe PWN, Warszawa.

Stoner J. A. F., Wankel Ch. (1996), Kierowanie, Państwowe Wydawnictwo Ekonomiczne, Warszawa.

Sztumski J. (1987), Konflikt społeczny, Wydawnictwo Uniwersytetu Śląskiego, Katowice. Webber A. (1990), Zasady zarządzania organizacjami, Państwowe Wydawnictwo Ekonomiczne, Warszawa.

Zbiegień-Maciąg L., Pawnik W. (1995), Zarządzanie organizacja, Wydawnictwo Akademii Górniczo-Hutniczej, Kraków.

Zieleniewski J. (1969), Organizacja i zarzqdzanie, Wydawnictwo Naukowe PWN, Warszawa.

Zimniewicz K. (1991), Techniki zarządzania, Państwowe Wydawnictwo Ekonomiczne, Warszawa.

\section{CLASSIFICATION OF CONFLICTS IN ENTERPRICE}

Abstract: The article has cognitive character. This article aims to identify the basic types of conflicts, taking into account the different criteria for their division. The multitude of situations happen in practice, makes difficult the proper classification, which undoubtedly is an obstacle in their diagnosis and delays the process of solving them. Knowledge of different types of conflicts can contribute to the proper allocation existing situations of conflict. Brief description may be a contribution to solve them faster.

K e y w ord s: conflicts, the enterprise. 